\title{
Spatial variability of vegetation index and soil properties in an integrated crop-livestock system
}

\author{
Alberto C. de C. Bernardi ${ }^{1}$, Célia R. Grego ${ }^{2}$, Ricardo G. Andrade 3 , \\ Ladislau M. Rabello ${ }^{4} \&$ Ricardo Y. Inamasu ${ }^{4}$ \\ ${ }^{1}$ Embrapa Pecuária Sudeste. São Carlos, SP. E-mail: alberto.bernardi@embrapa.br (Corresponding author) \\ ${ }^{2}$ Embrapa Monitoramento por Satélite. Campinas, SP. E-mail: celia.grego@embrapa.br \\ ${ }^{3}$ Embrapa Gado de Leite. Juiz de Fora, MG. E-mail: ricardo.andrade@embrapa.br \\ ${ }^{4}$ Embrapa Instrumentação. São Carlos, SP. E-mail: ladislau.rabello@embrapa.br; ricardo.inamasu@embrapa.br
}

\section{Key words:}

soil fertility

soil electrical conductivity

VERIS

Landsat 5

NDVI

\begin{abstract}
A B S T R A C T
The knowledge of soil property spatial variability is useful for determining the rational use of inputs, such as the site-specific application of lime and fertilizer. The objective of this study was to evaluate the vegetation index and spatial variability of physical and chemical soil properties in an integrated crop-livestock system (ICLS). Soil samples were taken from a 6.9 ha area in a regular hexagon grid at 0-0.20 m depths. Soil P, K, Ca, Mg, and cation exchange capacity - CEC; base saturation; clay and sand were analyzed. Soil electrical conductivity (ECa) was measured with a contact sensor. The site was evaluated at the end of the corn season (April) and during forage production (October) using Landsat 5 images, remote sensing techniques and a geographic information system (GIS). Results showed that the normalized difference vegetation index (NDVI) was associated with ECa and soil parameters, indicating crop and pasture variations in the ICLS. Geostatistics and GIS were effective tools for collecting data regarding the spatial variability of soil and crop indicators, identifying variation trends in the data, and assisting data interpretation to determine adequate management strategies.
\end{abstract}

\section{Palavras-chave:}

fertilidade do solo

condutividade elétrica do solo VERIS

Landsat 5

NDVI

\section{Variabilidade espacial de índices de vegetação e propriedades do solo em sistema de integração lavoura-pecuária}

\section{R E S U M O}

O conhecimento da variabilidade espacial dos atributos físicos e químicos do solo é útil para o uso racional de insumos, como na aplicação localizada de corretivos e fertilizantes. Objetivou-se, nesta pesquisa, avaliar a variabilidade espacial dos índices de vegetação e atributos físicos e químicos do solo em um sistema de integração lavoura-pecuário (ILP). Uma área de 6,9 ha foi amostrada com grade regular hexagonal na profundidade de 0-0,20 m. Os valores no solo de P, K, Ca, Mg, e CTC, saturação por bases, argila e areia foram analisados. A condutividade elétrica aparente do solo (CEa) foi medida com um sensor de contato. O talhão foi avaliado no final do ciclo do milho (abril) e para a produção de pastagem (outubro) por imagens do satélite Landsat 5, utilizando-se técnicas de sensoriamento remoto e sistemas de informação geográfica (SIG). Os resultados mostraram que o índice de vegetação por diferença normalizada (NDVI) foi associado à CEa e aos parâmetros de solo indicando as variações da cultura do milho e pastagem em sistema ILP. A geoestatística e o SIG foram ferramentas eficazes para unir os dados de variabilidade espacial do solo e da cultura, indicar as tendências dos resultados e interpretar a informação para apoiar estratégias de manejo adequadas. 


\section{INTRODUCTION}

Integrated crop-livestock systems (ICLSs) rotate land use between grain crops and pasture to improve grass quality, recuperate degraded pasture, feed animals in the dry season, and improve grain yield through no-tillage management (Balbino et al., 2011).

Providing an adequate supply of nutrients is important for corn and forage production, and it is essential to maintain high quality and profitable yields in ICLSs. Lime and fertilizer are common inputs for highly weathered, low fertility, acidic soils in Brazil. However, soil fertility management without accounting for spatial variation within a field may directly affect crop yield (Bernardi et al., 2015).

Precision agriculture (PA) is a knowledge chain that assists farmers in making management decisions for different cropping systems to increase economic returns and decrease the negative environmental impact of agriculture through the management of spatial variability (Inamasu \& Bernardi, 2014).

Measurements of apparent soil electrical conductivity (ECa) can easily provide spatial data for characterizing variations in soil and yield (Kitchen et al., 2003; Serrano et al., 2010). ECa can be related to clay, water, soil nutrients, organic matter, cation exchange capacity and exchangeable $\mathrm{Ca}$ and $\mathrm{Mg}$ (Machado et al., 2006, 2015). These are also characteristics that affect crop productivity and can be helpful in interpreting spatial yield variations.

Remote sensing (RS) is another PA tool in which acquired images are transformed into vegetation indexes, which may be related to some crop variables (Schellberg et al., 2008; Bernardi et al., 2014; Escribano Rodríguez et al., 2014). Satellite-derived vegetation indexes have been widely used to estimate crop and grassland biomass; RS provides temporal and spatial patterns of ecosystem change and has been used to estimate the biophysical characteristics of crops and grasslands (Moges et al., 2004; Numata et al., 2007; Schellberg et al., 2008; Silva Júnior et al., 2013; Bernardi et al., 2014). Normalized difference vegetative indexes (NDVI) are commonly used to evaluate plant health, biomass, and nutrient content (Moges et al., 2004; Numata et al., 2007; Escribano Rodríguez et al., 2014).

The objective of this study was to evaluate the vegetation index and spatial variability of physical and chemical soil properties in a crop-livestock system under a no-tillage protocol.

\section{Material AND Methods}

The 6.9 ha field study was conducted at Embrapa Pecuária Sudeste, in Sao Carlos (22 $01^{\prime} \mathrm{S}$ and $47^{\circ} 54^{\prime} \mathrm{W}$; $856 \mathrm{~m}$ above sea level), State of Sao Paulo, Brazil from December 2008 to October 2009. The climate in this region is Cwa type (Köeppen), with low and high temperature yearly averages of 16.3 and $23.0^{\circ} \mathrm{C}$, respectively, and a total precipitation of 1502 $\mathrm{mm}$, falling mostly in summer. The soil type is a dystrophic Red-Yellow Latosol (331 $\mathrm{g} \mathrm{kg}^{-1}$ of clay) corresponding to a Haplorthox (Soil taxonomy).

A regular hexagon georeferenced sampling grid design with six sub-samples collected at $0-0.2 \mathrm{~m}$ depths was adopted for each hectare, and three more samples were taken in a transection along the field. Soil samples were carried out with an all-terrain vehicle (ATV) equipped with GPS and a stainless-steel screw auger with adjustable depth and electrical activation, which allowed for the demarcation of the points with their respective geographical coordinates.

Following Primavesi et al. (2005), soil pH measurements were made with water, organic carbon was determined by wet combustion, available $\mathrm{P}$ and exchangeable $\mathrm{K}^{+}$were found using the resin method, and Cation exchange capacity (CEC) was measured at the actual soil $\mathrm{pH}$ value, and base saturation $(\% \mathrm{~V})$ was determined. The densimeter method was used to analyze soil particle size fractions (clay and sand content).

ECa was measured using a Veris model 3100 sensor manufactured by Veris Technologies of Salina, KS. Measurements were carried out according to Eq. 1:

$$
\rho=\frac{\mathrm{IL}}{\mathrm{AV}}
$$

where:

$\rho \quad$ - soil electrical conductivity, $\mathrm{mS} \mathrm{m}^{-1}$;

I - electric current applied by the sensor to the ground, Ampere;

L - spacing between the pairs of electrodes, $m$;

A - area cross section of the electrodes (of the rotating discs) in contact with the ground, $\mathrm{m}^{2}$; and,

$\mathrm{V}$ - potential difference of the electromagnetic field generated in the soil, measured by pairs of electrodes, volts.

In the crop-livestock rotation system, the summer crop corn (Zea mays L. cv. BRS 3060) was sown together with the forage palisadegrass Piatã (Urochloa brizantha cv. Piatã) with no tillage after 3 growing seasons of palisadegrass Marandu (Urochloa brizantha cv. Marandu) pasture. The corn crop was sown with a $0.8 \mathrm{~m}$ interlinear space, using five plants per meter; the palisadegrass Piatã pasture was sown between the rows of corn at a density of $5 \mathrm{~kg}$ of seed per ha. Dolomite lime was uniformly applied to increase base saturation at $70 \%$ before planting. The corn was uniformly fertilized at planting with 30 $\mathrm{kg} \mathrm{ha}^{-1}$ of N, $100 \mathrm{~kg} \mathrm{ha}^{-1}$ of $\mathrm{P}_{2} \mathrm{O}_{5}, 55 \mathrm{~kg} \mathrm{ha}^{-1}$ of $\mathrm{K}_{2} \mathrm{O}$ and $1.4 \mathrm{~kg}$ $\mathrm{ha}^{-1}$ of $\mathrm{Zn}$, and the forage was not fertilized during planting. Nitrogen and K (urea and $\mathrm{KCl}$, respectively) were broadcast fertilized 60 days after planting in the amounts of $100 \mathrm{~kg}$ $\mathrm{ha}^{-1}$ of $\mathrm{N}$ and $100 \mathrm{~kg} \mathrm{ha}^{-1}$ of $\mathrm{K}_{2} \mathrm{O}$. The silage corn harvest was initiated in May, when the whole-plant water concentration was between 600 and $700 \mathrm{mg} \mathrm{kg}^{-1}$. After silage harvesting, the pasture was allowed to develop and was used for animal grazing in the next season.

Two Landsat Thematic Mapper 5 (TM5) scenes were used in this study, corresponding to the end of the corn season (April) and the beginning of the forage season (October). Images were aligned with digital base maps provided by the Instituto Nacional de Pesquisas Espaciais (INPE - Brazilian Space Agency). NDVI was calculated with Erdas Imagine 9.3 (Erdas Inc, Atlanta, Georgia, USA) in three steps: radiometric digital inter-calibration, monochromatic reflectance calculation and NDVI calculation. Landsat TM images were inter-calibrated to 
the corresponding Landsat ETM+ reflectance images using a relative radiometric calibration $\left(\mathrm{L}_{\lambda_{\mathrm{i}}}\right)$ approach calculated using Eq. 2 (Chander \& Markham, 2003):

$$
\mathrm{L}_{\lambda \mathrm{i}}=\mathrm{L} \min +\frac{\mathrm{L} \max -\mathrm{L} \min }{255} \mathrm{ND}
$$

where:

$\mathrm{L}_{\lambda \mathrm{I}} \quad$ - relative radiometric calibration;

Lmax and Lmin - maximum and minimum spectral radiances $\left(\mathrm{Wm}^{-2} \mathrm{sr}^{-1} \mu \mathrm{m}^{-1}\right.$ ) after 05/05/2003; and,

ND - digital number of each pixel.

After, the monochromatic reflectance calculations of each band $\left(\rho_{\lambda_{\mathrm{i}}}\right)$ were achieved using Eq. 3 proposed by Allen et al. (2002):

$$
\rho_{\lambda \mathrm{i}}=\frac{\pi \mathrm{L}_{\lambda \mathrm{i}}}{\mathrm{E}_{\lambda \mathrm{i}} \cos \theta_{\mathrm{z}} \mathrm{d}_{\mathrm{r}}}
$$

where:

$\mathrm{L}_{\lambda_{\mathrm{i}}} \quad$ - spectral radiance of each band;

$E_{\lambda i}$ - spectral solar irradiance of each band in the atmosphere $\left(\mathrm{W} \mathrm{m}^{-2} \mu \mathrm{m}^{-1}\right)$; and,

$\theta_{\mathrm{z}}$ - solar zenith angle, and $\mathrm{d}_{\mathrm{r}}$ is the relative distance earth-sun (astronomical unit - UA).

Then, the normalized difference vegetation index (NDVI) was calculated using Eq. 4 (Choudhury, 1987):

$$
\mathrm{NDVI}=\frac{\rho_{\mathrm{NIR}}-\rho_{\mathrm{R}}}{\rho_{\mathrm{NIR}}+\rho_{\mathrm{R}}}
$$

where:

$$
\rho_{\mathrm{NIR}} \text { and } \rho_{\mathrm{R}} \text { - percent near infrared and red reflectance, } \mathrm{nm} \text {. }
$$

Statistical parameters and geostatistical analyses were performed for all variables, focusing on the spatial continuity and dependence of soil and crop properties. Empirical directional semivariograms were calculated for the $\mathrm{x}$ - and $y$-directions. Semivariogram models were fitted to the empirical semivariograms $\gamma(\mathrm{h})$ using GEOEST (Vieira et al., 2002) to estimate the structure of the spatial variation of a variable $\mathrm{V}$ and the semivariance using Eq. 5:

$$
\hat{\gamma}(h)=\frac{1}{2 N(h)} \sum_{i=1}^{N(h)}\left[Z\left(x_{i}\right)-Z\left(x_{i}+h\right)\right]^{2}
$$

where:

$\mathrm{Z}\left(\mathrm{x}_{\mathrm{i}}\right)$ and $\mathrm{Z}\left(\mathrm{x}_{\mathrm{i}}+\mathrm{h}\right)$ - observed values of $\mathrm{Z}$ at location $\mathrm{x}$ and $\mathrm{x}+\mathrm{h}$, respectively;

$\mathrm{h}$ - separation distance; and,

$\mathrm{N}$ (h) - number of paired comparisons at distance h.

NDVI and ECa were estimated by ordinary kriging, while soil parameter properties were estimated using inverse distance weighting interpolation. Contour maps of estimates were prepared using Arc GIS 9 (Arc Map 9.2 - ESRI, Inc., Redlands, CA).

\section{Results AND Discussion}

The statistical parameters of all the analyzed variables are presented in Table 1. Mean, variance, coefficient of variation, minimum value, maximum value, skewness, and kurtosis were obtained to verify the existence of a central tendency and to determine the dispersion of the data. These values and the other standard statistical parameters are useful in evaluating the magnitude of the data dispersion around a central tendency value. The statistical parameters, including mean, variance, coefficient of variation, minimum value, and maximum value, indicate the amplitude and trend of variation of the analyzed data, and they are important for characterizing the data set. Based on the values presented in Table 1, most of the variables were distributed normally, as indicated by the proximity to zero for the skewness and kurtosis coefficients, with the exception of ECa and NDVI (October 31).

If a dataset is close to a normal distribution, the values for skewness and kurtosis coefficients approach zero (Vieira et al., 2002).

Soil pH, CEC, and sand content had low variability, with coefficient of variations below $10 \%$. Soil OM, K, P, clay contents and base saturation represented soil properties with medium variability $(\mathrm{CV}<30 \%)$, whereas Trotter et al. (2014) had found CV ranging from 35 to $66 \%$ for $\mathrm{P}, \mathrm{K}$ and S. ECa represented

\begin{tabular}{|c|c|c|c|c|c|c|c|c|c|c|c|}
\hline \multirow{2}{*}{$\begin{array}{l}\text { Statistical } \\
\text { parameters }\end{array}$} & \multirow{2}{*}{$\begin{array}{c}\text { NDVI } \\
\text { (April 22, 2009) }\end{array}$} & \multirow{2}{*}{$\begin{array}{c}\text { NDVI } \\
\text { (0ct 31, 2009) }\end{array}$} & \multirow{2}{*}{ 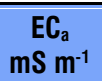 } & \multirow{2}{*}{$\mathrm{pH}_{\mathrm{H} 20}$} & \multirow{2}{*}{$\begin{array}{l}\mathrm{OM} \\
\mathrm{g} \mathrm{kg}^{-1}\end{array}$} & \multirow{2}{*}{$\begin{array}{c}P \\
\mathbf{m g ~ d m ^ { - 3 }}\end{array}$} & $\mathbf{K}$ & CEC & \multirow{2}{*}{$\begin{array}{l}\mathbf{V} \\
\%\end{array}$} & \multirow{2}{*}{\multicolumn{2}{|c|}{$\frac{\text { Clay Sand }}{\mathrm{g} \mathrm{kg}^{-1}}$}} \\
\hline & & & & & & & \multicolumn{2}{|c|}{$\mathrm{cmol}_{\mathrm{c}} \mathrm{dm}^{-3}$} & & & \\
\hline $\mathrm{N}$ & 79 & 74 & 9922 & 10 & 10 & 10 & 10 & 10 & 10 & 10 & 10 \\
\hline Minimum & 0.628 & 0.3169 & 0.400 & 5.90 & 27.00 & 3.0 & 0.80 & 10.70 & 21.64 & 215.0 & 569.0 \\
\hline Maximum & 0.764 & 0.8163 & 9.900 & 6.70 & 55.00 & 6.0 & 2.20 & 12.50 & 40.74 & 392.0 & 691.0 \\
\hline$\mu$ & 0.711 & 0.728609 & 1.342 & 6.26 & 39.47 & 3.8 & 1.20 & 11.69 & 30.53 & 297.6 & 640.2 \\
\hline Median & 0.712 & 0.7548 & 1.300 & 6.30 & 40.50 & 4.0 & 1.10 & 11.70 & 29.76 & 304.5 & 637.5 \\
\hline$\sigma$ & 0.029 & 0.081379 & 0.485 & 0.20 & 7.38 & 0,92 & 0.35 & 0.51 & 5.12 & 42.0 & 31.5 \\
\hline Variance & 0.001 & 0.006622 & 0.236 & 0.04 & 54.40 & 0.84 & 0.12 & 0.26 & 26.21 & 1763.6 & 992.1 \\
\hline CV (\%) & 4.03 & 11.17 & 36.16 & 3.27 & 18.69 & 24.2 & 25.64 & 4.35 & 16.77 & 14.11 & 4.92 \\
\hline Kurtosis & 0.931 & 9.421384 & 72.106 & -0.56 & -0.67 & 3.32 & 0.20 & -0.68 & -0.60 & -0.30 & 0.43 \\
\hline Skewness & -0.834 & -2.61833 & 5.529 & -0.01 & -0.01 & 1.00 & 0.65 & -0.40 & 0.35 & 0.07 & -0.81 \\
\hline
\end{tabular}
soil properties with high variability. According to Kravchenko (2003), the level of data variability is important for site-specific management, as soil properties with high variability are

Table 1. Descriptive statistics for NDVI, $\mathrm{EC}_{\mathrm{a}}$ and the chemical properties of a ICLS in Brazil

NDVI - Normalized difference vegetation index; ECa - Apparent soil electrical conductivity; ICLS - Integrated crop-livestock system

CV - Coefficient of variation equals standard deviation $(\sigma)$ divided by sample mean $(\mu)$ 
potentially better candidates to be managed on a site-specific basis than the more uniformly distributed soil properties. On the other hand, mapping soil properties with higher variability can be less accurate than soil properties with lower variability. Trends in the variation of soil attributes obtained in this study are consistent to those observed by Bernardi et al. (2014) for several soil parameters.

Experimental semivariograms for all variables were computed, and all fitted models were bounded (Table 2). The results showed that the full extent of the variation of NDVI and EC had been encountered at the spatial scale of this study. The parameters fitted to the semivariograms are shown in Table 2.
Table 2. Parameters for semivariograms models for NDVI and ECa of a ICLS in Brazil

\begin{tabular}{lcccc}
\hline \multicolumn{1}{c}{ Variable } & $\mathbf{C}_{0}$ & $\mathbf{C}$ & $\mathbf{A}$ & Model \\
$\mathrm{NDVI}$ - April 22 & 0.00020518 & 0.00081176 & 214.639 & Spherical \\
$\mathrm{NDVI}$ - October 31 & 0.00068261 & 0.0054747 & 128.387 & Spherical \\
$\mathrm{EC}_{\mathrm{a}}$ & 0.10169 & 0.077365 & 34.0573 & Spherical \\
\hline
\end{tabular}

NDVI - Normalized difference vegetation index; ECa - Apparent soil electrical conductivity; ICLS - Integrated crop-livestock system

The parameters are nugget variance $\left(C_{0}\right)$, sill of the auto-correlated variance $(C)$, and range of the spatial dependence $(A)$

The soil parameters measured (pH, O.M., P, K, CEC, V\%, clay and sand) had pure nugget effects and weak spatial dependence, probably due to the low-density grid adopted with 10 samples.
A.

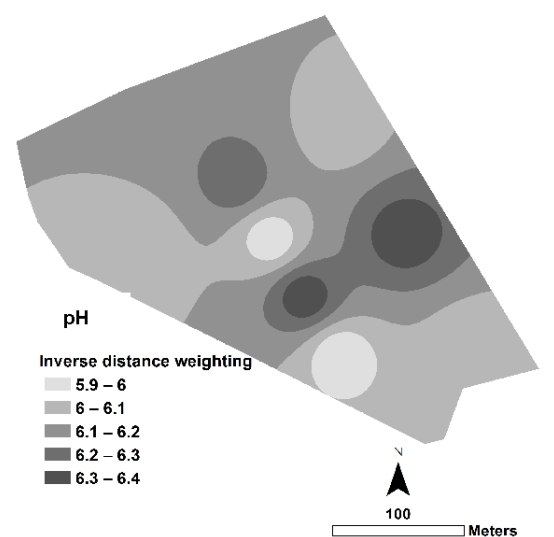

D.

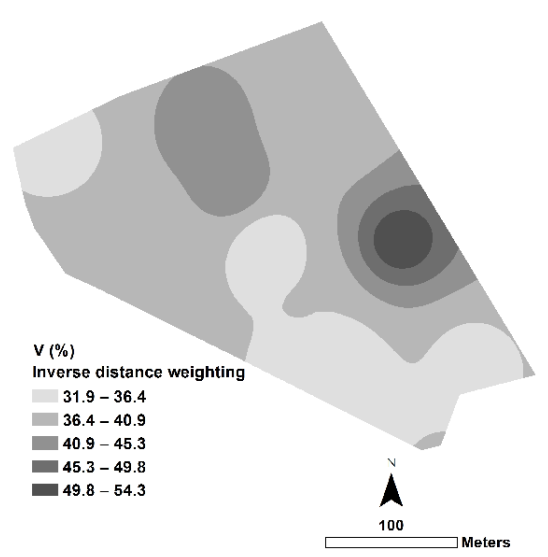

G.

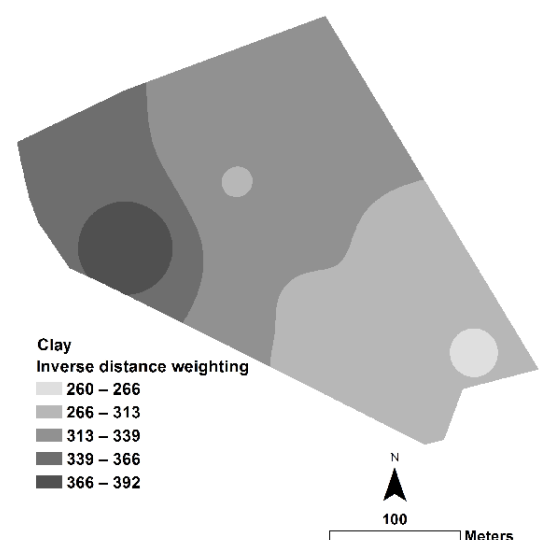

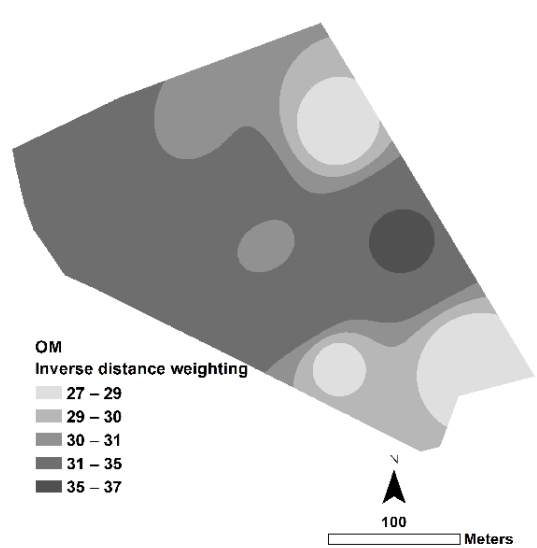

E.

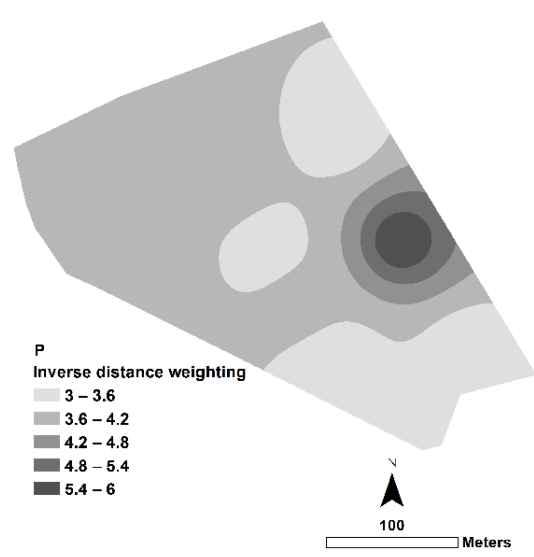

H.

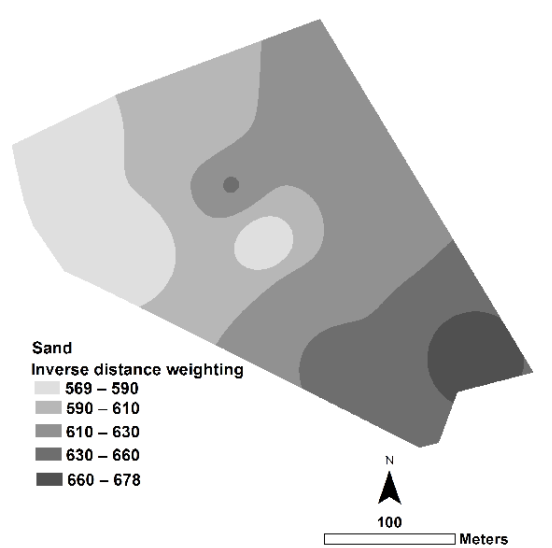

C.

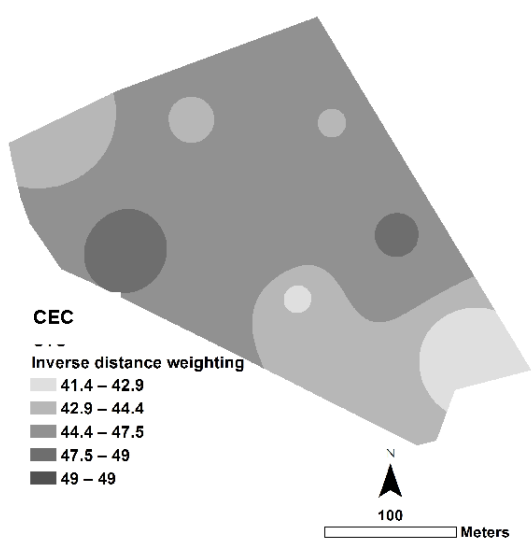

F.

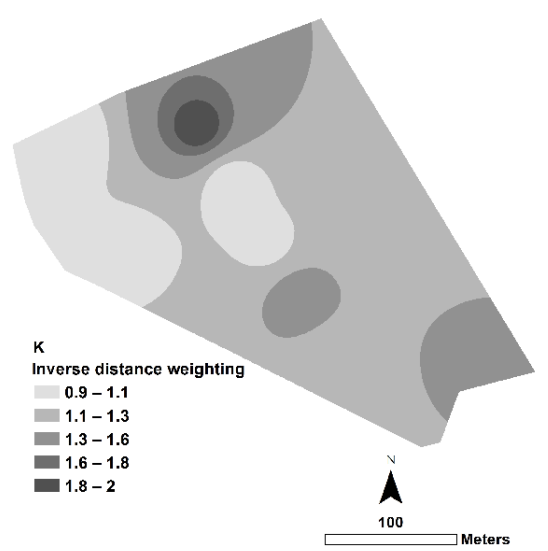

I.

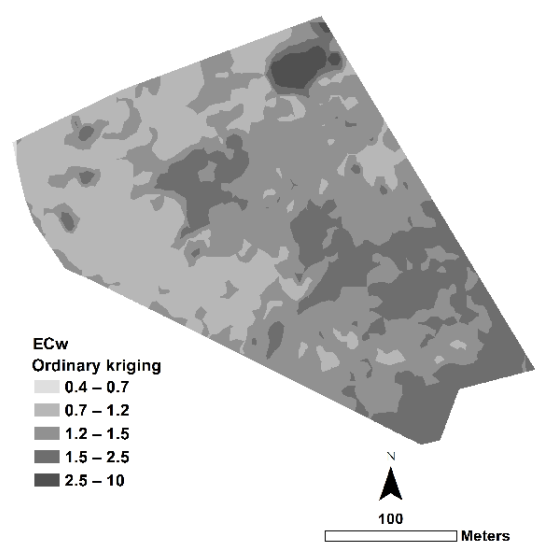

Figure 1. Maps of estimated inverse distance weighting of $\mathrm{pH}_{\text {water }}(\mathrm{A}) ; \mathrm{OM}-\mathrm{g} \mathrm{kg}^{-1}(\mathrm{~B}) ; \mathrm{CEC}-\mathrm{Cmol}_{\mathrm{c}} \mathrm{dm}^{-3}(\mathrm{C}) ; \mathrm{V} \%(\mathrm{D})$; $\mathrm{P}-\mathrm{mg} \mathrm{dm} \mathrm{m}^{-3}(\mathrm{E}) ; \mathrm{K}-\mathrm{cmol}_{\mathrm{c}} \mathrm{dm}^{-3}(\mathrm{~F})$; clay $-\mathrm{g} \mathrm{kg}^{-1}(\mathrm{G})$; sand $-\mathrm{g} \mathrm{kg}^{-1}(\mathrm{H})$; and ECw $-\mathrm{mS} \mathrm{m}^{-1}(\mathrm{I})$ of a ICLS in Brazil 
The spherical model was best adjusted to the experimental variograms of NDVI (both dates) and ECa. Ranges of spatial dependence from the semivariogram models were higher for NDVI, with values of 214 and $128 \mathrm{~m}$, than for ECa $(34 \mathrm{~m})$.

The maps presented in Figure 1 refer to the spatial distribution of the $\mathrm{pH}$ values in water; organic matter; resin $\mathrm{P}$ and $\mathrm{K}$; clay; sand; V\%; and CEC measured at 0 to $20 \mathrm{~cm}$ in depth. According to Raij et al. (1996), the values of $\mathrm{P}$ were considered very low ( 0 to $6 \mathrm{mg} \mathrm{dm}^{-3}$ ), the values of $\mathrm{K}$ were low (0.8 to $1.5 \mathrm{mmol}_{\mathrm{c}} \mathrm{dm}^{-3}$ ) to medium (1.6 to $3.0 \mathrm{mmol}_{\mathrm{c}} \mathrm{dm}^{-3}$ ), and the base saturation rates were low (26 to $50 \%$ ).

These results show that the soil does not offer the plants sufficient quantities and proportions of these elements. There is an area in the middle-right side of the plot where values of pH, O.M., P, V\%, and CEC are slightly higher than the rest of the studied area. These results may inform decisions regarding liming and fertilization, successfully addressing soil acidity and nutrient availability issues. Trotter et al. (2014) established site-specific nutrient fertilizer maps based on soil nutrient availability.

These results indicate that a grid spacing of $128 \mathrm{~m}$ would be adequate for the characterization of NDVI spatial variability for this site. Then, the $30 \times 30 \mathrm{~m}$ resolution Landsat 5 imageries would be adequate. Crop variation at this spatial scale probably reflects variables such as topography, soil type, and other related soil properties. This is true for ECa; a grid spacing of 34 $\mathrm{m}$ would identify the spatial variability, and the high-density sampling process with Veris in parallel transects would provide the necessary results within that distance.

Kriged estimates for ECa were contoured and mapped, so that their patterns of variation in the field could be examined (Figure 1I). This map shows that since soil ECa is associated with soil properties, such as soil texture, soil organic matter, cation exchange capacity, and exchangeable $\mathrm{Ca}$ and $\mathrm{Mg}$, the regions with higher values of ECa correspond with areas of higher soil parameter values ( $\mathrm{pH}, \mathrm{OM}, \mathrm{pH}, \mathrm{P}, \mathrm{CEC}$ and $\mathrm{V} \%$ ). Serrano et al. (2010) observed positive correlations of ECa with soil pH but no significant correlations between EC and parameters, such as clay and soil organic matter. The strain

A.

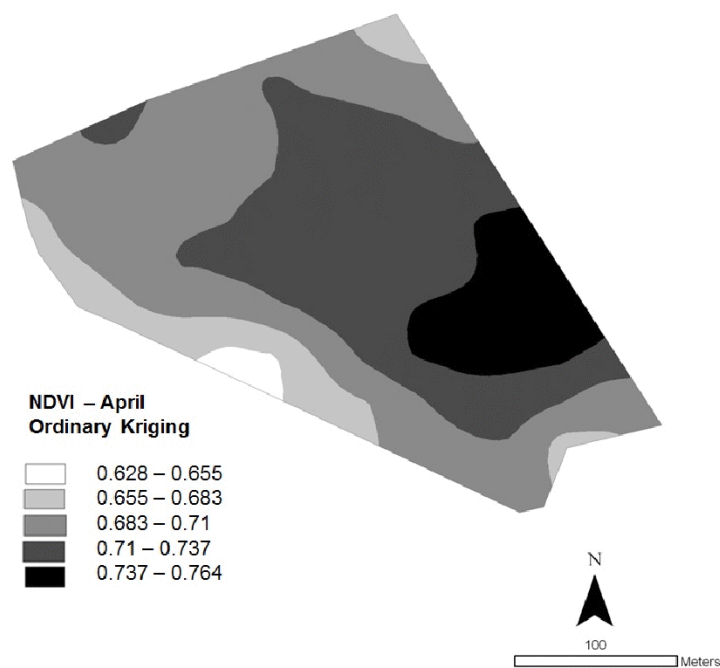

of high-ECa (2.5 to $\left.10 \mathrm{mS} \mathrm{m}^{-1}\right)$ in the upper-right corner of the study area was due to the occurrence of an animal feedlot from the previous year. Cattle were fed at a trough in the area, causing a higher range of manure concentration.

Figure 2 illustrates the kriged map created based on a semivariance analysis of NDVI for corn and pasture. NDVI relies on the spectral contrast between red and near-infrared bands and is sensitive to leaf-chlorophyll content and the leaf area index (LAI) of vegetation (Numata et al., 2007). NDVI values are also highly correlated with biomass production (Silva Júnior et al., 2013; Escribano Rodríguez et al., 2014); the results suggest that higher pasture NDVI values indicate greater shoot production.

The satellite image for corn demonstrated the same pattern that was observed for the soil parameters and ECa. This also provides evidence that the crop variation in the studied field reflects the variation in soil properties. These results confirm that the spectral data from RS can be used to detect and define management zones. These management zones are areas with different physical-chemical soil properties that influence plant yield and quality (Schellberg et al., 2008; Silva Júnior et al., 2013; Escribano Rodríguez et al., 2014). Moreover, the results indicated that differences could be clearly and consistently distinguished, even with a mix of crops (corn and pasture).

There was an inverse relationship between the NDVI values of the first evaluation date (corn - Figure 2A) and the second (forage - Figure 2B). In other words, areas with high corn NDVI values were the same regions with low grass NDVI values. This apparent contradiction can be explained by the fact that corn and grass were sown together (in different rows), but corn growth was supported by fertilization. Due to the shading caused by corn during the period of cultivation, the grass grew slowly, especially because both species have a $\mathrm{C} 4$ metabolism of $\mathrm{CO}_{2}$ fixation, a characteristic that makes them light-demanding. Therefore, it was easier for the corn crop to access light, complete the cycle and produce satisfactorily (Portes et al., 2000). Typically, in such integrated systems, after corn harvesting, the competition for light ends and the forage grows more rapidly (Balbino et al., 2011). Therefore, in places
B.

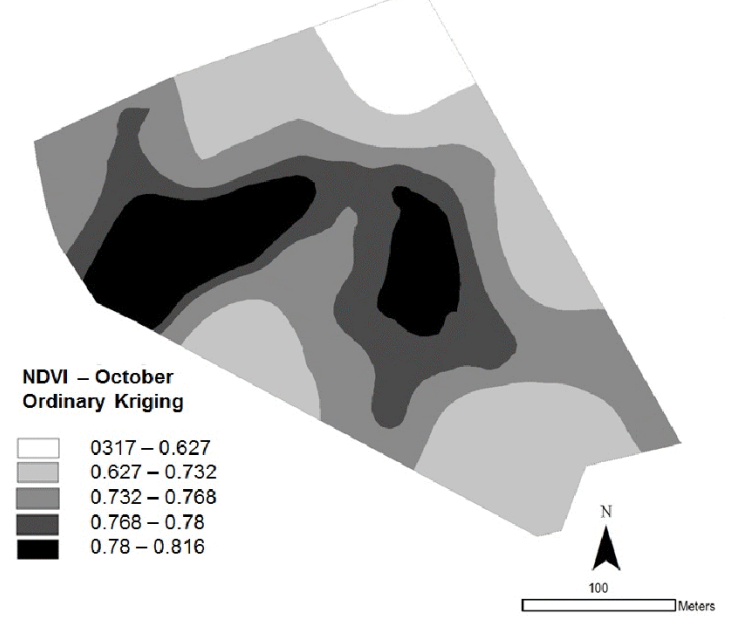

Figure 2. Map of kriged estimates of NDVI for corn (A) and pasture (B) in a ICLS in Brazil 
where corn grew well due to better soil fertility, there was more shade and consequently less vegetative growth of the grass. In the areas with lower corn NDVI, pasture had better vegetative growth, as indicated by the higher grass NDVI values.

\section{Conclusions}

1. The results from this study showed that NDVI values were associated with ECa and soil parameters, representing crop and pasture variations in an integrated crop-livestock system under a no-tillage protocol.

2. Geostatistics and GIS were effective tools for collecting data regarding the spatial variability of soil and crop indicators, identifying variation trends in the data, and assisting data interpretation to determine adequate management strategies.

\section{Literature Cited}

Allen, R.; Tasumi, M.; Trezza, R. SEBAL - Surface Energy Balance Algorithms for Land: Advanced training and user's manual. Kimberly: Idaho Implementation, 2002. 97p.

Balbino, L. C.; Cordeiro, L. A. M.; Silva, V. P. da; Moraes, A. de; Martínez, G. B.; Alvarenga, R. C.; Kichel, A. N.; Fontaneli, R. S.; Santos, H. P. dos; Franchini, J. C.; Galerani, P. R. Evolução tecnológica e arranjos produtivos de sistemas de integração lavoura-pecuária-floresta no Brasil. Pesquisa Agropecuária Brasileira, v.46, p.1-12, 2011. https:// doi.org/10.1590/S0100-204X2011001000001

Bernardi, A. C. de C; Bettiol, G. M.; Grego, C. R.; Andrade, R. G.; Rabello, L. M.; Inamasu, R. Y. Ferramentas de agricultura de precisão como auxílio ao manejo da fertilidade do solo. Cadernos de Ciência \& Tecnologia, v.32, p.211-227, 2015.

Bernardi, A. C. de C.; Rabello, L. M, Inamasu, R. Y.; Grego, C. R.; Andrade, R. G. Variabilidade espacial de parâmetros físicoquímicas do solo e biofísicos de superfície em cultivo do sorgo. Revista Brasileira de Engenharia Agrícola e Ambiental, v.18, p.623630, 2014. https://doi.org/10.1590/S1415-43662014000600009

Chander, G.; Markham, B. Revised Landsat - 5 TM radiometric calibration procedures and postcalibration dynamic ranges. IEEE Transactions on Geoscience and Remote Sensing, v.41, p.26742677, 2003. https://doi.org/10.1109/TGRS.2003.818464

Choudhury, B. J. Relationships between vegetation indices, radiation absorption, and net photosynthesis evaluated by a sensitivity analysis. Remote Sensing of Environment, v.22, p.209-233, 1987. https://doi.org/10.1016/0034-4257(87)90059-9

Escribano Rodríguez, J. A.; Hernández Díaz-Ambrona, C. G.; Tarquis Alfonso, A. M. Selection of vegetation indices to estimate pasture production in dehesas. Pastos, v.44, p.6-18, 2014.

Inamasu, R. Y.; Bernardi, A. C. de C. Agricultura de precisão. In: Bernardi, A. C. de C.; Naime, J. M.; Resende, A. V.; Bassoi, L. H.; Inamasu, R. Y. (ed.). Agricultura de precisão: Resultados de um novo olhar. Brasília: EMBRAPA, 2014. p.21-33.

Kitchen, N. R.; Drummond, S. T.; Lund, E. D.; Sudduth, K. A.; Buchleiter, G. W. Soil electrical conductivity and topography related to yield for three contrasting soil-crop systems. Agronomy Journal, v.95, p.483-495, 2003. https://doi.org/10.2134/agronj2003.0483

Kravchenko, A. N. Influence of spatial structure on accuracy of interpolation methods. Soil Science Society of America Journal, v.67, p.1564-1571, 2003. https://doi.org/10.2136/sssaj2003.1564
Machado, F. C.; Montanari, R.; Shiratsuchi, L. S.; Lovera, L. H.; Lima, E. de S. Spatial dependence of electrical conductivity and chemical properties of the soil by electromagnetic induction. Revista Brasileira de Ciência do Solo, v.39, p.1112-1120, 2015. https:// doi.org/10.1590/01000683rbcs20140794

Machado, P. L. O. de A.; Bernardi, A. C. de C.; Valencia, L. I. O.; Molin, J. P.; Gimenez, L. M.; Silva, C. A.; Andrade, A. G. de; Madari, B. E.; Meirelles, M. S. P. M. Mapeamento da condutividade elétrica e relação com a argila de Latossolo sob plantio direto. Pesquisa Agropecuária Brasileira, v.41, p.1023-1031, 2006. https://doi. org/10.1590/S0100-204X2006000600019

Moges, S. M.; Raun, W. R.; Mullen, R. W.; Freeman, K. W.; Johnson, G. V.; Solie, J. B. Evaluation of green, red and near infrared bands for predicting winter wheat biomass, nitrogen uptake and final grain yield. Journal of Plant Nutrition, v.27, p.1431-1441, 2004. https://doi.org/10.1081/PLN-200025858

Numata, I.; Roberts, D. A.; Chadwick, O. A.; Schimel, J.; Sampaio, F. R.; Leonidas, F. C.; Soares, J. V. Characterization of pasture biophysical properties and the impact of grazing intensity using remotely sensed data. Remote Sensing of Environment, v.109, p.314-327, 2007. https://doi.org/10.1016/j.rse.2007.01.013

Portes, T. de A.; Carvalho, S. I. C. de; Oliveira, I. P. de; Kluthcouski, J. Análise do crescimento de uma cultivar de braquiária em cultivo solteiro e consorciado com cereais. Pesquisa Agropecuária Brasileira, v.35, p.1349-1358, 2000. https://doi.org/10.1590/S0100204X2000000700009

Primavesi, A. C.; Andrade, A. G.; Alves, B. J. R.; Rosso, C.; Batista, E. M.; Prates, H. T.; Ortiz, F. R.; Mello, J.; Ferraz, M. R.; Linhares, N. W.; Machado, P. L. O. A.; Moeller, R.; Alves, R. C. S.; Silva, W. M. Métodos de análise de solo. In: Nogueira, A. R. A.; Souza, G. B. (ed.). Manual de laboratórios: Solo, água, nutrição vegetal, nutrição animal e alimentos. São Carlos: Embrapa Pecuária Sudeste, 2005. p.67-130.

Raij, B. van; Cantarella, H.; Quaggio, J. A.; Furlani, A. M. C. (ed.). Recomendações de adubação e calagem para o Estado de São Paulo. 2.ed. Campinas: IAC, 1996. 285p. Boletim Técnico, 100

Schellberg, J.; Hill, M. J.; Gerhards, R.; Rothmund, M.; Braun, M. Precision agriculture on grassland: Applications, perspectives and constraints. European Journal of Agronomy, v.29, p.59-71, 2008. https://doi.org/10.1016/j.eja.2008.05.005

Serrano, J. M.; Peça, J. O.; Marques da Silva, J. R.; Shahidian, S. Mapping soil and pasture variability with an electromagnetic induction sensor. Computers and Electronics in Agriculture, v.73, p.7-16, 2010. https://doi.org/10.1016/j.compag.2010.03.008

Silva Júnior, M. C. da; Pinto, F. de A. de C.; Queiroz, D. M. de; Vieira, L. B.; Resende, R. C. de. Using an aerial system of remote sensing to detect different nutritional status in Brachiaria decumbens. Engenharia Agrícola, v.33, p.1049-1062, 2013. https://doi. org/10.1590/S0100-69162013000500016

Trotter, M.; Guppy, C.; Haling, R.; Trotter, T.; Edwards, C.; Lamb, D. Spatial variability in $\mathrm{pH}$ and key soil nutrients: Is this an opportunity to increase fertiliser and lime-use efficiency in grazing systems? Crop \& Pasture Science, v.65, p.817-827, 2014. https:// doi.org/10.1071/CP13449

Vieira, S. R.; Millete, J.; Topp, G. C.; Reynolds, W. D. Handbook for geoestatistical analysis of variability in soil and climate data. In: Alvarez, V. V. H.; Schaefer, C. E. G. R.; Barros, N. F.; Mello, J. W. V.; Costa, J. M. (ed.). Tópicos em ciência do solo. Viçosa: Sociedade Brasileira de Ciência do Solo, 2002. p.1-45. 